\title{
HUBUNGAN FILSAFAT DENGAN ILMU PENGETAHUAN DAN RELEVANSINYA DI ERA REVOLUSI INDUSTRI 4.0 (SOCIETY 5.0)
}

\section{Muhammad Rijal Fadli}

Pascasarjana, Universitas Negeri Yogyakarta, Indonesia

Email: rijalfadli.co@gmail.com

\section{Abstrak}

Filsafat dan ilmu pengetahuan merupakan upaya manusia dalam memahami suatu konsep dan metode dari sebuah disiplin ilmu. Perubahan zaman dan perkembangan telah mengantar filsafat ke suatu konfigurasi dengan menunjukkan bagaimana "pohon ilmu pengetahuan" bertumbuh mekar dan bercabang secara subur dari masing-masing disiplin ilmu. Tujuan penelitian ini menelaah filsafat dan ilmu pengetahuan serta relevansinya di era Revolusi Industri 4.0. Penelitian ini menggunakan metode hermeneutik dalam menjelaskan realitas yang terjadi dengan unsur-unsur interpretasi dan deskripsi. Filsafat dan ilmu pengetahuan sangat diperlukan kehadirannya di tengah perkembangan IPTEK yang ditandai dengan menajamnya spesialisasi ilmu pengetahuan, karena dengan mempelajari filsafat para ilmuwan diharapkan akan dapat menyadari atas keterbatasan dirinya agar tidak terperangkap ke dalam sikap arogansi intelektual. Counter discourse terhadap perkembangan IPTEK tidak dapat dilakukan, melainkan untuk dapat mengurangi dampak negatif dari adanya teknologi itu sendiri. Di era Revolusi Industri 4.0 dan Society 5.0 kelompok masyarakatnya heterogen, sehingga sangat kompleks timbul masalah-masalah terkait berkembangnya teknologi dan dapat mengubah pola pikir kehidupan manusia ke pola kehidupan yang lebih canggih dengan tenaga teknologi seperti robot dan internet. Maka, keilmuan yang dijadikan sebagai tonggak aksiologis dalam mengarahkan, mengendalikan perkembangan IPTEK secara positif untuk kepentingan umat manusia dan lingkungannya adalah filsafat dan ilmu pengetahuan.

Kata kunci: Filsafat, Ilmu Pengetahuan, Revolusi Industri 4.0, Society 5.0 


\section{Abstract}

Philosophy and science are human efforts in understanding the concepts and methods of a scientific discipline. The changing times and developments have ushered the philosophy of a configuration by showing how the "tree of knowledge" flourishes and branches off from the respective disciplines. The purpose of this research is to examine philosophy and science and their relevance in the era of the Industrial Revolution 4.0. This research method uses the hermeneutic method in explaining the reality that occurs with elements of interpretation and description. The results of the research can be described that the study of the relationship between philosophy and science has progressed so intensely. Philosophy and science are indispensable for their presence during the development of science and technology which is marked by the sharpening of scientific specialization, because by studying philosophy scientists are expected to be aware of their limitations so as not to be trapped into intellectual arrogance. It is impossible to counter-discourse developing science and technology, but rather to reduce the negative impact of the technology itself. In the era of the Industrial Revolution 4.0 and Society 5.0, the community groups were heterogeneous, so that very complex problems arose related to the development of technology and could change the mindset of human life to a more sophisticated pattern of life with the power of technology such as robots and the internet. Thus, the science that is used as an axiological milestone in directing and controlling the development of science and technology in a positive way for the benefit of mankind and its environment is philosophy and science.

Keywords: Philosophy, Science, Industrial Revolution 4.0, Society 5.0.

\section{PENDAHULUAN}

Filsafat merupakan pijakan atau landasan berpikir manusia dalam dunia akademik sebagai penalaran akal dalam mencari dan mendalami sebuah ilmu pengetahuan. Filsafat dan ilmu pengetahuan secara terus menerus selalu mengalami transformasi guna untuk menuntaskan problematik yang dihadapi seiringan perkembangan zaman. Sejak lahir dan berkembangnya filsafat dan ilmu pengetahuan memiliki peranan/pengaruh yang besar terhadap dunia akademik. Secara historis keberadaan filsafat dan ilmu 
pengetahuan terus mengalami dinamika setiap periodisasi guna adanya tuntutan zaman. Secara mendasar telah mengalami perubahan dari pemikiran terdahulu, sehingga diadakannya eksplorasi mendalam untuk menyelesaikan problematikaproblematika yang ada.

Perubahan sosial memicu munculnya semangat asketisme intelektual masyarakat, dari situ menimbulkan etos intelektual. Hal inilah yang mendorong masyarakat untuk terus berkarya dan berkembang dengan hal-hal baru guna meningkatkan kemakmuran kehidupannya, sehingga menjadi masyarakat modern. Pada abad 17 ditandai dengan meletusnya Revolusi Industri yang melahirkan masyarakat modern, telah menciptakan berbagai pemikiran dan pandangan idealis yang memiliki praksis dan dampak besar terhadap kehidupan masyarakat pada zaman tersebut (Tasnur \& Sudrajat, 2020). Perubahan tersebut tidak begitu mengherankan, sebab apabila dicermati yang telah terjadi bahwa paham yang muncul pada suatu zaman biasanya hasil dari respons terhadap rentetan peristiwa-peristiwa yang terjadi secara berdampingan dan mengokohkan antara satu dengan yang lainnya. Berabad-abad lamanya dominasi gereja merupakan alasan mendasar dari lahirnya positivisme dan diperkuat oleh adanya sekularisme. Penguatan aliran tersebut semakin lengkap ketika liberalisme yang melahirkan kapitalisme menggunakan positivisme yang digunakan sebagai alat legitimasi keberadaannya dalam semua unsur sendi kehidupan masyarakat modern, sehingga secara tidak langsung tujuan mendasar dari filsafat sedikit demi sedikit mengalami pergeseran dari tujuan substansinya.

Dewasa ini semakin berkembangnya zaman masyarakat modern telah mencapai Revolusi Industri 4.0, di mana semua roda kehidupan masyarakat didukung dengan canggihnya teknologi. Perilaku sosial dan pola kehidupan masyarakat telah berubah secara drastis akibat pengaruh dari Revolusi Industri. Perkembangan teknologi yang melahirkan era Revolusi Industri 4.0 tidak hanya sekedar membuka interaksi sosial secara luas, tetapi juga mendisrupsikan di berbagai bidang kehidupan manusia 
(Prasetyo \& Trisyanti, 2018). Sedangkan Society 5.0 merupakan tatanan kebutuhan masyarakat yang berpusat pada manusia (human-centered) dan berbasis teknologi (technology based) (Fukuda, 2020). Revolusi Industri 4.0 dan Society 5.0 telah menghadirkan tatanan kehidupan yang baru bagi masyarakat, di mana semua perilaku masyarakat akan dibuat secara mudah dalam memenuhi segala unsur kehidupan.

Hal tersebut merupakan masalah yang mendasari dari dampak positivisme atau dapat disebut dengan one dimensional man. Kajian ini telah dilakukan di Frankfurt Jerman, hasil analisisnya menjelaskan tentang masyarakat modern yang terbelenggu dengan adanya hasil ciptaan yang dilahirkan oleh aliran positivisme dan cara pandangan kebenarannya berlandaskan pada pembuktian secara empiris dan teruji secara saintifik. Kajian tersebut kemudian melahirkan paham baru yakni paham Frankfurt, sehingga muncul permasalahan di mana tujuan awal filsafat sebenarnya dianggap tidak memayungi semua kebutuhan substansi manusia.

Penelitian Amsal Bakhtiar (2012) mengemukakan bahwa secara substansial dan historis filsafat dan ilmu pengetahuan memiliki peranan penting dalam memberikan pengaruh besar terhadap kehidupan manusia. Kedua hal ini tidak dapat dipisahkan satu sama lain karena saling terintegrasi. Jika ditelusuri filsafat dan ilmu pengetahuan berperan dalam membawa perubahan peradaban manusia. Penelitian Hidayatullah (2006: 234) menerangkan bahwa peradaban Yunani merupakan tempat pertama kali filsafat ditemukan. Seiring dengan berkembangnya filsafat dalam masyarakat Yunani kuno telah mengubah pola pikir mereka dari yang awalnya berpandangan mitosentris menjadi logo sentris. Keterkaitan filsafat dan ilmu pengetahuan sangat berpengaruh besar terhadap pengetahuan manusia dari segala sesuatu, pengaruh tersebut telah membawa perubahan terhadap peradaban manusia ke taraf yang lebih maju, seperti halnya peradaban manusia saat ini (Tafsir, 2005). Kajian ini memiliki konsep yang sama dengan penelitian tersebut, namun subtansial yang penulis kaji melihat filsafat di era saat ini (Revolusi Industri 
4.0 dan Society 5.0), filsafat harus berperan dalam berpijak agar dapat menjawab tuntutan zaman yang selalu berkembang.

Berdasarkan uraian di atas, tujuan dari artikel ini akan fokus dan lebih komprehensif mengenai hubungan filsafat dengan ilmu pengetahuan dan relevansinya di era Revolusi Industri 4.0 atau Society 5.0. Secara hipotesis filsafat dengan ilmu pengetahuan memiliki hubungan satu sama lain, karena keduanya merupakan kegiatan berpikir khas dari manusia. Filsafat dan ilmu pengetahuan ditujukan pada proses dan hasil, jika dilihat dari hasilnya keduanya sama-sama hasil daripada berpikirnya akal manusia secara sadar. Apabila dilihat dari prosesnya menunjukkan sesuatu kegiatan yang berusaha untuk memecahkan permasalahan dalam kehidupan manusia, dengan metode dan prosedur tertentu secara sistematis dan kritis. Seperti halnya dalam menghadapi pola kehidupan manusia di era Revolusi Industri 4.0 atau Society 5.0, manusia akan memikirkan dengan menggunakan metode dan prosedur tertentu untuk menghadapi dan menjalani perubahan tersebut.

\section{PEMBAHASAN}

\section{Filsafat dan Ilmu Pengetahuan}

Istilah "filsafat" secara etimologis merupakan persamaan kata falsafah (bahasa Arab) dan philosophy (bahasa Inggris), berasal dan bahasa Yunani (philosophia). Kata philosophia merupakan kata majemuk yang terdiri dan kata (philos) dan (sophia). Kata philos berarti kekasih, bisa juga berarti sahabat. Adapun sophia berarti kebijaksanaan atau kearifan, bisa juga berarti pengetahuan (Rapar, 2001: 5). Secara harfiah philosophia berarti yang mencintai kebijaksanaan atau sahabat pengetahuan. Istilah philosophia telah diindonesiakan menjadi "filsafat", ajektifnya adalah "filsafat" dan bukan "filosofis". Apabila mengacu kepada orangnya, kata yang tepat digunakan yaitu "filsuf' dan bukan "filosof' (Suaedi, 2016). Kecuali bila digunakan kata "filosofi" dan bukan "filsafat", maka ajektifnya yang tepat ialah "filosofis", sedangkan yang mengacu kepada orangnya ialah kata filosof. 
Filsafat sangat terkait dengan tradisi pemikiran-pemikiran Barat. Hingga saat ini para ilmuwan menyepakati bahwa filsafat pertama kali hadir di Yunani pada sekitar abad ke- 7 SM. Pada awal kemunculan berkembangnya filsafat, ilmu pengetahuan masih menjadi bagian yang tidak terpisahkan dari filsafat. Corak pemikiran filsafat pada awal munculnya dikenal dengan istilah alam. Tokoh-tokoh yang memiliki pengaruh besar ketika itu yakni, Thales dan Anaximander. Selain itu dalam sejarah filsafat dikenal beberapa kategorisasi dan filosof yang hidup pada kurun waktu berbeda. Kategori tersebut adalah filsafat filsafat klasik, filsafat abad pertengahan dan filsafat modern (Agriyanto \& Rohman, 2015: 40).

Dalam filsafat klasik munculnya Socrates menandai dimulainya filsafat periode klasik. Nama-nama filosof klasik yang terkenal di antaranya adalah, Socrates (470-399 SM), Plato (427-374 SM), Aristoteles (384-322 SM) dan Plotinus (205-70 SM). Sedangkan dalam filsafat abad pertengahan muncul nama-nama besar seperti, John Scotus Eriugena (815-877 M), Santo Anselmus (1034-1109), Roscellinus (1050-1120 M), Santo Thomas Aquinas (1225-1247 M). Sementara itu pada filsafat modern yang berpengaruh bsesar adalah, Copernicus (1473-1543), Kepler (1571-1630 M), Galileo Galilei (1564-1642), Rene Descartes (1596-1650 M), Isaac Newton (1643-1727), Immanuel Kant (1724-1804). Filosof periode modern adalah aktor yang paling berperan terhadap perkembangan ilmu pengetahuan modern, kontribusi mereka hingga sampai saat ini masih bisa dirasakan (Machamer, 2008: 97).

Ilmu pengetahuan yang diperoleh melalui filsafat di peradaban Yunani Kuno mengalami kemajuan dari waktu ke waktu. Kemajuan tersebut ditandai dengan adanya pergulatan pemikiran di antara para filsuf. Filsuf pertama yang muncul di Yunani Kuno (Pra Socrates) adalah Thales yang hidup pada tahun (624-545 SM). Menurut Thales zat yang membentuk segala sesuatu di alam semesta ini adalah air. Tak sependapat dengan yang dikemukakan oleh Thales, Anaximander (620-546 SM) membantah pendapat Thales dan menyatakan bahwa, substansi asal bukanlah air. Berdasarkan hal tersebut memperlihatkan bahwa adanya 
diskursus tentang ilmu pengetahuan telah memungkinkan wawasan manusia terus berkembang, seiring lahirnya filsuf-filsuf baru (Carnap, 2012).

Menurut tradisi filsafat yang tua, istilah Yunani philosophia digunakan Phythagoras untuk menyebut gerak, pencarian akan kebijaksanaan dan kebenaran yang biasa dilakukan oleh manusia. Kebijaksanaan dalam bentuk yang utuh dan sempurna hanya ada pada yang ilahi, sementara manusia yang terbatas sudah merasa puas dengan menegaskan diri sebagai pencinta dan bukan pemilik kebijaksanaan dan kebenaran utuh. Melalui akal budinya, manusia hanya mampu mendekatkan diri kepada kebenaran yang utuh. Manusia tidak akan pernah meraihnya secara lengkap dan sempurna satu kali untuk selamanya (Zaprulkhan, 2016: 6).

Filsafat juga merupakan studi tentang seluruh fenomena kehidupan dan pemikiran manusia secara kritis yang dijabarkan dalam konsep mendasar. Filsafat tidak didalami dengan melakukan eksperimen-eksperimen dan percobaan-percobaan, akan tetapi dengan mengutarakan masalah secara sama, mencari solusi untuk itu, memberikan argumentasi dan alasan yang tepat untuk solusi tertentu. Setelah membahas sekilas mengenai definisi filsafat (filosofi), maka bisa disimpulkan bahwa filsafat memiliki suatu upaya menemukan kebenaran tentang hakikat sesuatu yang ada, melalui penggunaan kemampuan akal secara optimal. Kebenaran yang dihasilkan oleh pemikiran filsafat adalah jawaban dalam bentuk gagasan atau ide. Adapun tujuan dari filsafat ialah untuk memperoleh kebenaran yang bersifat dasar dan menyeluruh dalam sistem yang konseptual. Filsafat menghasilkan pula kebenaran yang bersifat abstrak, spekulatif akan tetapi tidak mampu mengetahui bagaimana cara mengadakannya.

Sebelum membahas apa itu ilmu pengetahuan, maka harus mengupas dulu pengertian ilmu dan pengetahuan. Ilmu berasal dari bahasa arab 'ilm, yang berarti memahami, mengerti, atau mengetahui. Ilmu mengacu kepada suatu hal yang melebihi pengetahuan. Pada zaman dahulu, yang dikatakan orang yang berilmu jelas merupakan orang yang telah dianggap memiliki 
kemampuan yang didapat melalui syarat-syarat tertentu. Orang yang dianggap berilmu merupakan orang yang lolos ujian dan syarat-syarat yang menunjukkan predikat kelayakan yang dimilikinya (Soyomukti, 2011: 152). Ilmu merupakan kegiatan akal budi untuk menjelaskan kenyataan empiris secara spesifik menurut tiga kriteria utama: rasional, metodis, dan sistematis. Istilah rasional, bisa dikatakan bahwa apa yang diklaim oleh suatu ilmu sebagai kebenaran dapat diterima karena masuk akal, yakni logis, kritis, dan terbuka untuk perbaikan. Jadi, apa yang rasional tidak kebal kritik (Poespowardojo \& Seran, 2015: 9).

Sedangkan pengetahuan mencakup segala kegiatan dengan cara dan sarana yang digunakan maupun segala hasil yang diperolehnya. Dalam memahami "pengetahuan" kita perlu memahami tentang tindakan "mengetahui". Sebagaimana kegiatan yang dilakukan oleh manusia memiliki akibat atau hasil, demikian pula tindakan "mengetahui" tentu saja juga menghasilkan sesuatu, yaitu "pengetahuan". Pengetahuan merupakan segenap hasil dari kegiatan untuk mengetahui sesuatu obyek (dapat berupa suatu hal atau peristiwa yang dialami subyek), misalnya: pengetahuan tentang benda, tentang tumbuh-tumbuhan, tentang binatang, tentang manusia, atau pengetahuan tentang peristiwa peperangan (Wahana, 2016: 46). Pengetahuan merupakan segala sesuatu yang diketahui yang diperoleh dari persentuhan panca indera terhadap objek tertentu. Pengetahuan pada dasarnya merupakan hasil dari proses melihat, mendengar, merasakan, dan berpikir yang menjadi dasar manusia dan bersikap dan bertindak (Makhmudah, 2018: 203).

Ilmu pengetahuan adalah insting akal manusia yang secara sistematis dalam menciptakan kebutuhan (teori) baru sebagai pemenuhan hasrat atas rasa ingin tahu (Wilujeng, 2014: 104). Ilmu pengetahuan (pengetahuan ilmiah) kelanjutan konseptual dari ciriciri "ingin tahu" sebagai kodrat manusiawi. Rasa ingin tahu manusia boleh dikatakan tak pernah ada batasnya. Selalu ingin mencari dan menemukan yang baru. Dalam kehidupannya manusia selalu berhadapan dengan berbagai peristiwa dan gejala di 
lingkungan. baik yang menyangkut alam, maupun manusia. Didorong rasa ingin tahunya manusia berupaya untuk menemukan jawabannya. Ilmu pengetahuan terus berkembang melalui kajiankajian yang dilakukan para ilmuwan (Jalaludin, 2013: 91). Ilmu pengetahuan digunakan sebagai pijakan manusia untuk mencari teori-teori baru dengan metode dan prosedur tertentu agar memperoleh tujuan yang telah ditentukan. Disisi lain, ilmu pengetahuan harus bersifat sistematis dan teratur berdasarkan metodologi tujuannya agar mencapai generalisasi keilmuan yang diinginkan.

Ilmu pengetahuan hasil dari rangkaian aktivitas manusia yang rasional dan kognitif yang terdiri dari berbagai metode berupa aneka prosedur dan tata langkah sehingga menghasilkan kumpulan pengetahuan yang sistematis mengenai gejala-gejala kealaman, kemasyarakatan atau perorangan untuk tujuan mencapai kebenaran, memperoleh pemahaman, memberikan penjelasan, ataupun melakukan penerapan (Kirom, 2011: 102). Adapun menurut Surojiyo (2008: 57) definisi ilmu pengetahuan melibatkan setidaknya enam macam komponen, yakni masalah (problem), sikap (attitude), metode (method), aktivitas (activity), kesimpulan (conclution), dan pengaruh (effects).

Berdasarkan uraian di atas, ilmu pengetahuan yakni ilmu bertujuan mencapai kebenaran ilmiah tentang objek tertentu, yang bisa diperoleh melalui pendekatan atau cara pandang (approach), metode, dan sistem tertentu. Ilmu pengetahuan bisa diciptakan manusia karena didorong oleh rasa ingin tahu manusia yang tidak berkesudahan terhadap objek, pikiran, atau akal budi yang menyangsikan kesaksian indera, karena indera dianggap sering menipu. Ilmu pengetahuan bagi manusia mempunyai kemungkinan untuk mencapai pengetahuan yang lebih sempurna daripada pengetahuan biasa, yang lebih tinggi derajatnya yang hendak memberikan "insight" (pemahaman yang mendalam).

Ilmu pengetahuan dibangun atas kerja sama pendekatan akal dan intuisi. Akal memiliki keterbatasan penalaran yang kemudian disempurnakan oleh intuisi yang sifatnya pemberian atau bantuan, 
sedangkan pemberian dari intuisi masih belum tersusun rapi, sehingga dibutuhkan bantuan nalar untuk menyistematisasikan pengetahuan-pengetahuan yang bersifat pemberian itu (Ladyman, 2012: 36). Dengan pengertian lain, akal membutuhkan intuisi, dan begitu pula sebaliknya, intuisi membutuhkan akal. Keduanya saling membutuhkan bantuan dari pihak lainnya untuk menyempurnakan pengetahuan yang dicapai masing-masing.

Ilmu pengetahuan merupakan sebuah rangkaian konseptual atau teori yang saling berkaitan dan memberi tempat untuk pengkajian secara kritis menggunakan metode ilmiah yang bersifat sistematik, objektif dan universal. Ilmu pengetahuan memang berdasarkan "pengetahuan biasa", yang disempurnakan, diperluas, supaya pasti dan benar, sehingga manusia bisa mendekati apa yang dicita-citakannya. Secara sederhana ilmu pengetahuan dapat diartikan sebagai pengetahuan yang diatur secara sistematis dan langkah-langkah pencapaiannya dapat dipertanggungjawabkan secara teoritis.

Dalam memperoleh pengetahuan ada tiga masalah pokok yang biasanya harus diperhatikan oleh manusia pencari pengetahuan: (1) apakah yang ingin ia ketahui? (2) bagaimanakah cara memperoleh pengetahuan? dan (3) apakah nilai pengetahuan tersebut bagi dirinya?. Dalam usaha memperoleh pengetahuan dengan menjawab beberapa pertanyaan tersebut, maka manusia akan menghasilkan buah pemikiran salah satunya ialah ilmu. Karena ilmu salah satu dari pengetahuan yang diperoleh oleh manusia. Secara epistemologis, ilmu merupakan pengetahuan yang didapat melalui proses tertentu yang dinamakan metode keilmuan. Metode inilah yang membedakan ilmu dengan buah pemikiran yang lainnya. Jadi, ilmu adalah pengetahuan yang diperoleh dengan menerapkan metode keilmuan (Hidayatullah, 2006: 131).

Ilmu pengetahuan terdapat berbagai macam, yang masingmasing berlain-lain lapangan dan metodenya. Selanjutnya bagaimanakah menggolong-golongkan, membeda-bedakan ilmu pengetahuan itu. Dunia kita terbagi atas berbagai lapangan pengalaman yang masing-masing diliputi oleh ilmu 
pengetahuannya sendiri. Terdapatlah ilmu alam, ilmu pasti, sosiologi, ilmu hayat, ilmu bumi, ilmu jiwa. ilmu kedokteran, ilmu pekerjaan sosial, pedagogik dan sebagainya. Jadi tampaklah asas perbedaan itu di antaranya:

a. Objek atau lapangan ilmu pengetahuan, tentang ilmu pengetahuan belum cukup karena mungkin terjadi ada dua atau lebih ilmu pengetahuan yang mengenai obyek yang sama, padahal merupakan ilmu pengetahuan yang berlainan. Misalnya: ilmu jiwa, ilmu kedokteran, ilmu mendidik, sosiologi, filsafat. Semua itu mempelajari manusia, obyeknya manusia Bahkan juga ilmu hukum, ilmu ekonomi, ilmu hayat, ilmu bangsa-bangsa, itu semua mengenai manusia pula. Maka apakah yang membedakan berbagai ilmu pengetahuan itu. Pada garis besarnya obyek atau lapangan ilmu pengetahuan itu ialah alam dan manusia. Oleh karena ada ahli yang membagi ilmu pengetahuan itu atas dua bagian besar yaitu kelompok ilmu pengetahuan alam dan kelompok ilmu pengetahuan manusia (Salam, 2012: 15). Jadi yang membedakan antara satu ilmu Pengetahuan dengan pengetahuan lainnya adalah obyek material atau lapangan ilmu pengetahuan itu. Apabila obyek materialnya sama maka yang membedakannya ialah obyek formalnya atau sudut pandangannya.

b. Sudut pandang, untuk menerangkan hal ini lebih lanjut, maka kita harus memperhatikan bagaimana obyek itu dipandang. Jadi asas perbedaan kedua ialah sudut pandang. Inilah yang membedakan antara ilmu-ilmu pengetahuan, menentukan sifat-sifat ilmu dan metode yang dipakai. Misalnya: ilmu kedokteran yang mempelajari manusia dilihat dan sudut tubuhnya yaitu sekadar sakit dan harus disembuhkan. Mengapa sudut pandang ini begitu Penting? Sesungguhnya manusia itu adalah terbatas, dari berbagai barang-barang itu ia hanya dapat melihat satu sudut saja. Sebaliknya satu obyek dapat dipandang dari berbagai-bagai sudut. Mempelajari obyek harus sampai habis-habisan justru 
arti mempelajari dari berbagai-bagai sudut (Wahana, 2016: 16).

Landasan ilmu pengetahuan terutama diarahkan pada komponen-komponen yang menjadi tiang penyangga bagi eksistensi ilmu, tiang penyangga itu ada tiga macam yaitu ontologi, epistemologi, dan aksiologi.

a. Ontologi adalah teori tentang ada dan realitas. Ontologi merupakan ilmu hakikat bagian dari metafisika yang mengadakan penyelidikan terhadap sifat dan realitasnya. Ontologi juga mempelajari hakikat dan digunakan sebagai dasar untuk memperoleh pengetahuan atau dengan kata lain menjawab tentang pertanyaan apakah hakikat ilmu itu (Okasha, 2016: 277).

b. Epistemologi merupakan cabang dari filsafat ilmu yang membahas tentang apa yang kita ketahui dan bagaimana cara mengetahuinya. Sehingga epistemologi di sini mengkaji dan mencoba menemukan ciri-ciri umum dan hakikat dari pengetahuan manusia, bagaimana pengetahuan itu diperoleh dan diuji kebenarannya. Pokok bahasan epistemologi meliputi hakikat dan sumber pengetahuan, metode memperoleh pengetahuan, dan kriteria kesahihan pengetahuan (Mufid, 2013: 20).

c. Aksiologi merupakan ilmu pengetahuan yang menyelidiki hakikat nilai yang pada umumnya ditinjau dari sudut pandang kefilsafatan. Aksiologi meliputi nilai-nilai, parameter bagi apa yang disebut sebagai kebenaran atau kenyataan itu, sebagaimana kehidupan kita yang menjelajahi berbagai kawasan, seperti kawasan sosial, kawasan fisik material dan kawasan simbolik yang masing-masing menunjukkan aspeknya sendiri (Komara, 2012: 14).

\section{Hubungan Filsafat dengan Ilmu Pengetahuan}

Filsafat dan ilmu pengetahuan memiliki hubungan satu sama lain, bila melihat realitas hubungan filsafat dan ilmu pengetahuan bahwa semuanya merupakan dari kegiatan manusia. 
Kegiatan manusia diartikan dalam sebuah prosesnya dan juga dalam hasilnya. Bila dilihat dari hasilnya, keduanya merupakan hasil daripada berpikir manusia secara sadar. Bila dilihat dari segi prosesnya, menunjukkan suatu kegiatan yang berusaha untuk memecahkan masalah-masalah dalam kehidupan manusia (untuk memperoleh kebenaran dan pengetahuan), dengan menggunakan metode-metode atau prosedur-prosedur tertentu secara sistematis dan kritis.

Filsafat dan ilmu pengetahuan adalah satu kesatuan dan memiliki hubungan yang saling melengkapi antara satu dengan lainnya. Perbedaan yang terdapat dari keduanya bukan untuk dipertentangkan, melainkan untuk saling melengkapi, dan saling mengisi. Pada hakikatnya, perbedaan itu terjadi disebabkan cara pendekatan yang berbeda. Maka dalam hal ini perlu membandingkan antar filsafat dan ilmu pengetahuan, yang menyangkut perbedaan-perbedaan maupun titik temu di antaranya.

Semua keilmuan sudah dibicarakan di dalam filsafat, bahkan beberapa ilmu pengetahuan lahir dari filsafat, berarti ilmu yang memisahkan diri dari filsafat. Misalnya matematika, astronomi, fisika, kimia, biologi, psikologi, dan sosiologi. Ilmu juga bersifat analitis, ilmu pengetahuan hanya menggarap salah satu lapangan pengetahuan sebagai objek formalnya (Varpio \& Macleod, 2020). Sedangkan filsafat belajar dari ilmu pengetahuan dengan menekankan keseluruhan dari sesuatu (sinoptis), karena keseluruhan mempunyai sifat sendiri yang tidak ada pada bagianbagiannya. Ilmu bersifat deskriptif tentang objeknya agar dapat menemukan fakta-fakta, teknik-teknik, dan alat-alat (Zaprulkhan, 2016: 76).

Filsafat tidak hanya melukiskan sesuatu, melainkan membantu manusia untuk mengambil keputusan tentang tujuan, nilai dan tentang apa-apa yang harus diperbuat manusia. Filsafat tidak netral, karena faktor-faktor subjektif memegang peranan yang penting dalam berfilsafat, ilmu mulai dengan asumsi-asumsi. Filsafat juga mempunyai asumsi-asumsi dan menyelidiknya atau 
merenungkannya karena ia meragukan terhadap asumsi tersebut. Ilmu pengetahuan menggunakan eksperimentasi terkontrol sebagai metode yang khas. Verifikasi terhadap teori dilakukan dengan jalan mengujinya dalam praktik berdasarkan penginderaan. Sedangkan filsafat dengan melalui akal pikiran yang didasarkan kepada semua pengalaman insani, sehingga dengan demikian filsafat dapat menelaah masalah-masalah yang tidak dapat dicarikan penyelesaiannya oleh ilmu (French \& McKenzie, 2016).

Berdasarkan penjelasan di atas, bahwa hubungan filsafat dan ilmu pengetahuan saling berkaitan karena semuanya merupakan kegiatan manusia. Hubungan keduanya diibaratkan filsafat sebagai induknya ilmu sedangkan ilmu pengetahuan sebagai anak filsafat. Mengapa demikian, karena filsafat sifatnya lebih luas atau universal objeknya. Sedangkan ilmu pengetahuan objeknya terbatas karena hanya di dalam bidang tertentu. Filsafat dengan ilmu pengetahuan dapat saling bertemu sebab kedua-duanya menggunakan metode pemikiran reflektif dalam usaha untuk menghadapi fakta-fakta dunia dan kehidupan. Keduanya menunjukkan sikap kritik, dengan pikiran terbuka dan kemauan yang tidak memihak, untuk mengetahui hakikat kebenaran. Mereka berkepentingan untuk mendapatkan pengetahuan yang teratur.

Ilmu membekali filsafat dengan bahan-bahan yang deskriptif dan faktual yang sangat penting untuk membangun filsafat. Tiap filsuf dan suatu periode lebih condong untuk merefleksikan pandangan ilmiah pada periode tersebut. Sementara itu, ilmu pengetahuan melakukan pengecekan terhadap filsafat, dengan menghilangkan ide-ide yang tidak sesuai dengan pengetahuan ilmiah. Sedangkan Filsafat mengambil pengetahuan yang terpotong-potong dan berbagai ilmu, kemudian mengaturnya dalam pandangan hidup yang lebih sempurna dan terpadu. Dalam hubungan ini, kemajuan ilmu pengetahuan telah mendorong kita untuk menengok kembali ide-ide dan interpretasi kita, baik itu dalam bidang ilmu pengetahuan maupun dalam bidang-bidang lain. Sebagai salah satu contoh, konsep evolusi mendorong kita untuk meninjau kembali pemikiran kita, hampir dalam segala 
bidang. Kontribusi yang lebih jauh, yang diberikan filsafat terhadap ilmu pengetahuan, adalah kritik tentang asumsi, postulat ilmu dan analisa kritik tentang istilah-istilah yang dipakai (Juhaya, 2003: 13).

Hubungan Ilmu dengan Filsafat pada mulanya ilmu yang pertama kali muncul ialah filsafat dan ilmu-ilmu khusus menjadi bagian dari filsafat. Sedangkan filsafat merupakan induk dari segala ilmu karena menjelaskan tentang abstraksi/sebuah yang ideal. Filsafat tidak terbatas, sedangkan ilmu terbatas sehingga ilmu menarik bagian filsafat agar bisa dimengerti oleh manusia. Filsafat dan ilmu saling terkait satu sama lain, keduanya tumbuh dari sikap refleksi, ingin tahu, dan dilandasi kecintaan pada kebenaran. Filsafat dengan metodenya mampu mempertanyakan keabsahan dan kebenaran ilmu, sedangkan ilmu tidak mampu mempertanyakan asumsi, kebenaran, metode, dan keabsahannya sendiri. Ilmu merupakan masalah yang hidup bagi filsafat dan membekali filsafat dengan bahan-bahan deskriptif dan faktual yang sangat perlu untuk membangun filsafat. Filsafat dapat memperlancar integrasi antara ilmu-ilmu yang dibutuhkan. Filsafat adalah meta ilmu, refleksinya mendorong peninjauan kembali ideide dan interpretasi baik dari ilmu maupun bidang-bidang lain. Ilmu merupakan konkretisasi dari filsafat. Filsafat dapat dilihat dan dikaji sebagai suatu ilmu, yaitu ilmu filsafat. Sebagai ilmu, filsafat memiliki objek dan metode yang khas dan bahkan dapat dirumuskan secara sistematis. Filsafat dan ilmu pengetahuan mengkaji seluruh fenomena yang dihadapi manusia secara kritis refleksi, integral, radikal, logis, sistematis, dan universal (kesemestaan) guna mencapai tujuan yang diinginkannya.

\section{Menalaah Filsafat, Ilmu Pengetahuan dan Revolusi Industri 4.0 (Society 5.0) \\ Telaah filsafat, ilmu pengetahuan dan Revolusi Industri dapat} dilihat secara mendalam melalui pendekatan historis. Perkembangan hubungan antara filsafat dan ilmu pengetahuan mengalami kemajuan yang begitu intens. Permulaan sejarah filsafat di Yunani hampir meliputi seluruh pemikiran teoritis. Dalam 
perkembangannya ilmu pengetahuan jika dilihat secara mencolok ada kecenderungan yang lain, sebab filsafat Yunani kuno yang tadinya satu kesatuan menjadi terpecah belah. Dengan munculnya ilmu pengetahuan di abad 17, maka mulailah terjadi perpisahan antara filsafat dan ilmu pengetahuan. Sebelum abad 17 filsafat dan ilmu pengetahuan tidak lepas atau identik dengan filsafat. Sejalan dengan pendapat Van Peursen menjelaskan bahwa dahulu kala ilmu merupakan bagian dari kefilsafatan, sehingga pendefinisian mengenai ilmu pengetahuan bergantung pada sistem filsafat yang telah dianutnya (Schrijvers, 2018).

Lebih lanjut, dalam perkembangannya filsafat telah mengantarkan adanya suatu konfigurasi dengan menunjukkan bagaimana "pohon ilmu pengetahuan" telah bertumbuh mekar dan bercabang secara subur. Cabang dari masing-masing disiplin ilmu melepaskan diri dari batang filsafatnya, berkembang serta mengikuti metodologinya sendiri-sendiri. Semakin lama semakin tampak kemajuan ilmu pengetahuan dengan munculnya ilmu-ilmu baru dan pada akhirnya memunculkan sub-sub ilmu pengetahuan baru bahkan seiring berkembangnya zaman disiplin ilmu mengarah yang lebih khusus seperti spesialis-spesialis.

Ilmu pengetahuan dalam perkembangannya dengan pendekatan empiris menurut Auguste Comte (1798-1857) yang dituliskan dalam karyanya Cours de Philosphie Positive mengajarkan bahwa cara berpikir manusia dalam masyarakat akan mencapai puncaknya di tahap positif, setelah tahapan teologis dan metafisik. Pengistilahan positif memiliki arti eksplisit dengan muatan filsafati, maksudnya bahwa yang benar dan yang nyata haruslah konkret, eksak, akurat, dan memberi kemanfaatan (Levine, 2018).

Francis Bacon (1561-1626) memelopori teori observasi, eksperimentasi, dan komparasi juga ikut menyemarakkan pesatnya perkembangan ilmu pengetahuan. Para ilmuan setelahnya seperti Helmholtz, Pasteur, Darwin, Clerk Maxwell yang berhasil menemukan ilmu-ilmu baru dalam penelitian ilmiahnya. Semuanya memberikan isyarat bahwa dunia Barat telah berhasil melakukan 
tinggal landas untuk mengarungi dirgantara ilmu pengetahuan yang tiada bertepi.

"Knowledge is power" kata tersebut diserukan oleh Francis Bacon bahwa ilmu pengetahuan bukan hanya sekedar mitos belaka tetapi sudah menjadi etos. Seruan tersebut melahirkan pemahaman dan sikap pandang manusia yang meyakini kemampuan rasionalitas untuk menguasai dan meramalkan masa depan, dan optimismenya, berinovasi secara kreatif dalam membuka rahasiarahasia keilmuan. Setelah itu masyarakat Barat menjadi masyarakat yang tiada hentinya tanpa temuan-temuan baru yang muncul secara historis, kronologis, berurutan dan berdampingan sebagai alternatif.

Revolusi ilmu pengetahuan terus berlanjut di abad 20 atas teori relativitasnya Einstein yang merombak filsafat Newton yang semula dianggap mapan, di samping teori kuantumnya yang telah mengubah persepsi ilmu pengetahuan mengenai sifat-sifat dasar dan perilaku materi, sehingga para pakar dapat melanjutkan penelitiannya dan berhasil mengembangkan ilmu-ilmu dasar seperti astronomi, kimia, fisika, biologi, molekuler, sebagaimana hasilnya dapat dinikmati oleh manusia di abad ke-21 saat ini.

Pergulatan besar sumber ilmu pengetahuan yang menunjang kemajuan ilmu di era sekarang ini, secara historis dimulai dari Rasionalisme bersama tokohnya Rene Descartes, Empirisme dengan tokohnya John Locke, dan Kritisisme bersama tokohnya Immanuel Kant. Pergulatan tersebut berpuncak pada pemikiran Agust Comte dengan aliran Positivismenya. Pada abad 19 merupakan masa jayanya paham positivisme yang kuat dan luas pengaruhnya di abad modern, ukuran kebenaran dinilai dari sudut pandang positivismenya. Di sini filsafat telah menjadi praktis bagi tingkah laku perbuatan manusia, sehingga tidak lagi memandang penting berpikir secara abstrak (Tasnur \& Sudrajat, 2020).

Tidak berselang lama setelah itu muncul paham baru yakni postmodern, kemunculan paham postmodern tidak lepas dari modernisme itu sendiri. Dalam paham modernisme mengandung makna serba maju, gemerlap, dan progresif. Modernisme telah 
menjanjikan pada masyarakat untuk membawa pada perubahan ke dunia yang lebih mapan dan semua kebutuhan akan dapat terpenuhi (Setiawan \& Sudrajat, 2018). Rasionalitas akan membantu kita menghadapi mitos-mitos dan keyakinan-keyakinan tradisional yang tak berdasar, yang membuat manusia tak berdaya dalam menghadapi perkembangan dunia ini.

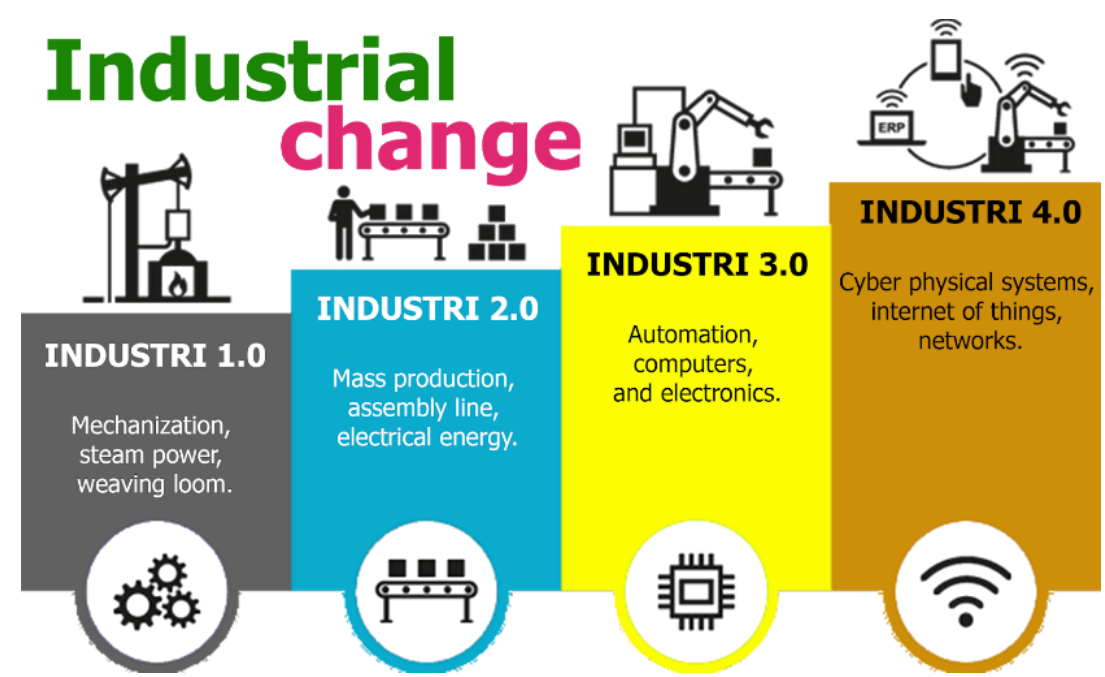

Gambar 1. Rangkaian Perkembangan Revolusi Industri dari Masa Ke Masa

Secara ambivalen pertumbuhan dan perkembangan IPTEK lebih mendasar, menyulur dan cepat telah dirasakan oleh umat manusia, sehingga berdampak kepada manusia baik positif dan terkadang negatif. Istilah perkembangan IPTEK saat ini sering dikenal dengan Revolusi Industri 4.0. Perkembangan tersebut ditandai dengan perkembangan IPTEK sebagai alat bantu yang digunakan oleh manusia dalam melakukan pekerjaan (Waston, 2019). Paham Revolusi Industri termaktub dalam teori evolusi, di mana beranggapan bahwa masyarakat mengalami sebuah perubahan secara bertahap. Adapun tahap perkembangan Revolusi Industri diawali dari Revolusi Industri 1.0, 2.0, 3.0, dan saat ini masih berjalan 4.0, rangkaian perkembangannya dapat dilihat pada gambar berikut. 
Revolusi Industri merupakan hasil dari perkembangan IPTEK yang dapat membantu manusia dalam menyelesaikan pekerjaan yang berbantuan teknologi. Sebelum adanya Revolusi Industri pekerjaan manusia dalam industri masih menggunakan tenaga murni tanpa bantuan teknologi. Secara bertahap dan berkembang pada 1700-an di Inggris Raya, telah terjadi perubahan manufaktur tenaga uap atau dikenal dengan Revolusi Industri 1.0. Memasuki abad ke-19 para ilmuan telah menemukan listrik atau dikenal dengan Revolusi Industri 2.0. Masuk di abad 20 muncul teknologi informasi dan elektronik yang masuk ke dalam dunia industri yaitu semua pekerjaan menggunakan sistem otomatisasi berbasis komputer dan robot dikenal dengan Revolusi Industri 3.0 (Rohida, 2018). Revolusi yang terakhir dikenal dengan Revolusi Industri 4.0 ditandai dengan penggunaan internet dalam dunia industri, di mana Internet menyambungkan seluruh komputer berada dalam satu jaringan raksasa dan dapat dikendalikan dalam sebuah smartphone (Schwab, 2019).

Revolusi Industri 4.0 pertama kali dicetuskan oleh para pakar Jerman di tahun 2011. Industri sekarang ini memasuki inovasi baru, semua proses produksi dan industri sudah berkembang pesat (Savitri, 2019). Beriringan dengan perkembangan ilmu pengetahuan telah muncul juga istilah Society 5.0. Istilah ini pertama kali dicestukan oleh Jepang tahun 2019 dengan mengusung konsep terbentuknya masyarakat super smart yang memiliki pola perilaku mengoptimalkan pemanfaatan internet of things, big data, dan artificial intelligence sebagai solusi atas tantangan kehidupan masyarakat yang lebih maju (Prasetyo \& Trisyanti, 2018).

Savitri (2019) menjelaskan Revolusi Industri 4.0 dan Society 5.0 merupakan gerakan nyata atas perkembangan IPTEK yang semakin canggih. Kemajuan ini akan menjadi tantangan tersendiri bagi perilaku kehidupan masyarakat, oleh karena itu untuk menghadapi munculnya Society 5.0 dibutuhkan sebuah inovasi dan terobosan baru guna dalam upaya menghadapi tantang dampak dari Society 5.0. Pemerintah Jepang mengadopsi konsep Society 5.0 sebagai antisipasi terhadap tren global akibat munculnya Revolusi Industri 
4.0. Society 5.0 memang dicetuskan untuk jawaban dan tantangan yang muncul atas dampak Revolusi Industri 4.0 yang dibarengi disrupsi dengan ditandai gejolak-gejolak ketidakpastian, kompleksitas dan ambiguitas saat ini (Ibda, 2019).

Situasi dan kondisi yang dihadapi saat ini tentu sangat berbeda dengan masa silam. Saat ini umat manusia telah paham dan menguasai IPTEK dalam kehidupannya. Cara hidup yang kurang dilandasi dengan suatu perangkat yang jelas dan mapan tentu tidak mungkin untuk dipertahankan jika tidak ingin menjadi budak dari IPTEK itu sendiri, dan jika tidak ingin menjadi manusia yang bermasa depan tanpa arah (Maksum, 2015). Maka, penguasaan ilmu pengetahuan secara canggih dengan kemampuan predikatnya dapat membantu manusia untuk mengelola pola kehidupan dalam meraih indahnya masa depan. Hal yang dipertaruhkan sebagai generasi penerus masa depan maka harus siap melatih skill guna melanjutkan kepemimpinan yang arif dan bijaksana dalam mengelola kehidupan sebagai bangsa yang besar dan terhormat. Dengan demikian, sangat diperlukannya sarana untuk meregenerasi dan mendidik calon ilmuwan menjadi arif dan bijaksana. Diperlukannya juga adanya inovasi baru yang mendasari perkembangan IPTEK agar kehadirannya lebih berimplikasi positif. Berdasarkan hipotesa para pakar, bahwa keilmuan yang dapat dijadikan tonggak aksiologis dalam mengarahkan perkembangan IPTEK secara positif untuk kepentingan umat manusia dan lingkungannya adalah filsafat dan ilmu pengetahuan. Karena, filsafat dan ilmu pengetahuan merupakan fondasi pijakan dalam berpikir untuk menentukan arah yang lebih baik dalam menghadapi tantangan zaman dipola kehidupan manusia yang baru.

\section{Relevansinya Filsafat dan Ilmu Pengetahuan di Era Revolusi Industri 4.0 (Society 5.0)}

Masyarakat yang hidup di era saat ini (abad 21) atau dikenal dengan masyarakat postmodern adalah sebuah kelompok masyarakat heterogen yang menyimpan banyak hal problematik 
yang tentunya sangat jauh lebih kompleks dibandingkan dengan masyarakat modern pada abad sebelumnya. IPTEK hadir menjadi suatu pijakan dari positivisme yang bertransformasi menjadi masalah besar di masyarakat modern. Dalam konteks kekinian masyarakat mempunyai masalah besar yang dihadapi, bahkan perkembangannya jauh lebih masif dan lebih kompleks, sehingga upaya transformasi penyelesainya dari berbagai masalah yang dihadapi harus dikaji lebih mendalam secara holistik dan komprehensif (Tasnur \& Sudrajat, 2020). Perkembangan IPTEK telah menjadi bukti nyata masalah yang dihadapi masyarakat saat ini atau lebih dikenal dengan istilah disrupsi (disruption), di mana terjadi perubahan secara besar-besaran di berbagai bidang sendi kehidupan masyarakat. Masyarakat superior harus mampu menyesuaikan dan beradaptasi diri terhadap sinkronisasi teknologi dari segala bidang, karena secara tidak langsung masyarakat saat ini akan memimpin jalannya roda kehidupan, yang nantinya akan mengontrol dan menghegemoni terhadap masyarakat lainnya. Jika ditinjau lebih jauh era ini akan membuat proses terjadinya dominasi dan distorsi sosial yang menyebabkan sekelompok masyarakat akan menguasai teknologi khususnya internet, sosial media, dan dunia maya.

Permasalahan lainnya di era disrupsi adalah fenomena dari arus globalisasi, yang diterjemahkan beragam oleh pemikir dunia. Saat ini globalisasi telah memasuki era Revolusi Industri 4.0 dan Society 5.0, di mana ilmu teknologi dan informasi sudah mendarah daging di kehidupan masyarakat seperti kendaraan otonom, kecerdasan buatan, dan internet yang saling mempengaruhi kehidupan (Savitri, 2019). Globalisasi secara tidak sadar telah mengubah tatanan dan struktur sosial, selain memberikan kemudahan dalam kehidupan. Secara historis perjalanan era globalisasi telah menunjukkan perubahan zaman yang memiliki pergerakan (core). Friedman, Ritzer dan Toffler menunjukkan pergerakan tersebut selalu dipicu oleh perkembangan dunia teknologi dan melahirkan era baru yakni Revolusi Industri 4.0, yang tidak hanya membuka atau memberikan jalan interaksi sosial secara 
luas, tetapi juga telah mendisrupsikan berbagai bidang di kehidupan manusia (Tasnur \& Sudrajat, 2020).

Derasnya arus globalisasi di tengah-tengah era Revolusi Industri 4.0 nampaknya berdampak pada peran manusia menjadi terdegradasi. Peranan manusia dalam dunia pekerjaan atau industri telah tergantikan oleh IPTEK seperti kecerdasan buatan, robot dan komputer. Hal ini bisa dikatakan sebagai dehumanisasi yang senantiasa menghantui kehidupan manusia, efek dari kecanggihan teknologi. Keadaan tersebut menimbulkan antitesa yang muncul yaitu Society 5.0, di mana peran manusia telah tergantikan oleh teknologi yang dibuat oleh manusia itu sendiri seperti robot dan kecerdasan buatan pada Revolusi Industri 4.0, maka istilah Society lahir sebagai bentuk kepedulian atas eksistensi manusia.

Di satu sisi, kita mengalami kesulitan untuk menganalisis patologi sosial yang hanya menggunakan satu pendekatan disiplin ilmu, sehingga sangat perlu adanya interdisipliner ilmu untuk mensintesiskan berbagai macam ilmu dalam menyelesaikan masalah sosial. Disisi lain filsafat hadir sebagai the mother of science yang dapat digunakan sebagai pisau analisis, maka dari itu di abad 21 ini filsafat dan ilmu pengetahuan benar-benar hadir dan mencapai puncaknya (Ibda, 2019). Filsafat dan ilmu pengetahuan pada abad 21 benar-benar berjaya untuk bekal terakhir bagi masyarakat yang ingin menjadi pemenang guna meminimalisir tantangan di era disrupsi ini.

Perkembangan ilmu pengetahuan membuat filsafat merefleksikan diri sebagai wadah keilmuan, agar tidak akan pernah mengenal titik henti dalam menjelajahi kawasan ilmiah guna mencapai kebenaran atau kenyataan, sesuatu yang tidak akan pernah habis untuk dipikirkan dan tidak akan selesai dibahas. Filsafat di sini diharapkan dapat berdiri ditengah-tengah ilmu pengetahuan, maksudnya filsafat bukan berarti menjadi semacam puncak ekstasi rasional ilmu-ilmu, mahkota ilmu-ilmu, atau status simbolis yang boleh diagungkan, meski tidak punya tangan untuk berbuat (Nasution, 2016). Filsafat yang dimaksudkan memiliki fungsi reflektif dan pragmatis yaitu menempatkan klaim-klaim 
analitis ilmu-ilmu pengetahuan dalam rangka mentransformasi abadi masyarakat dan umat manusia, sehingga filsafat nantinya dapat memberikan teoritis-etis bagi ilmu pengetahuan dan masyarakat.

Manusia dengan filsafat akan mampu menyublimasikan suatu disiplin ilmu yang menjadi tanggung jawabnya masing-masing, dan mengangkatnya kedataran filsafati, sehingga umat manusia dapat memahami perspektif serta berbagai kemungkinan arah perkembangannya, supaya manusia dapat melakukan spekulasispekulasi yang mendalam untuk menemukan teori-teori atau paradigma-paradigma baru demi kepentingan manusia (Rofiq, 2018). Perkembangan filsafat mengarahkan kepada strategi pengembangan ilmu pengetahuan, yang menyangkut etik dan heuristik, sampai pada dimensi kebudayaan untuk menangkal, dan tidak saja kegunaan/kemanfaatan ilmu saja tetapi mencakup arti dan maknanya bagi kehidupan manusia. Maka, dari sinilah betapa pentingnya kedudukan filsafat bagi perkembangan ilmu pengetahuan, apalagi saat ini di zaman Revolusi Industri 4.0 atau Society 5.0 dunia sudah mengarah pada IPTEK, semua kegiatan bisa digantikan oleh teknologi.

Keberadaan dan perkembangan IPTEK selalu saling mempengaruhi satu sama lain. Zaman now ini loncatan-loncatan penting bidang IPTEK telah terdapat inovasi-inovasi baru yang tentunya dapat berdampak positif dan juga negatif. Filsafat sebagai dasar bagi pengembangan IPTEK harus ikut turun pada kontekstualitasnya supaya kesadaran akan pemanfaatan teknologi tetap pada garis koridor atas kepentingan bersama (Ibda, 2019). Implikasi dari perkembangan dan penerapan IPTEK harus dikendalikan dengan dasar filsafat, tujuan agar etika ilmiah supaya tidak semakin jauh dari nilai-nilai etik, moral dan agama. Implikasi filsafat terhadap perkembangan IPTEK dijadikan dasar sebagai sarana pengujian penalaran ilmiah, sehingga manusia menjadi kritis terhadap kegiatan ilmiahnya. Usaha merefleksi, menguji, mengkritik asumsi dan metode keilmuan merupakan dari metode ilmiah yang sesuai dengan struktur ilmu pengetahuan, guna 
seorang ilmuan mengetahui hakikat dan landasan ilmu pengetahuan itu sendiri, serta memberikan pendasaran yang logis terhadap metode keilmuan tertentu (Habibah, 2017). Penerapan ilmu pengetahuan dan teknologi dalam kehidupan manusia harus dipertanggung jawabkan secara etis, agar manusia menyadari apa yang seharusnya dikerjakan untuk memperkuat harkat martabat manusia, baik dalam hubungannya sebagai pribadi, dengan lingkungan, dan sebagai makhluk yang bertanggung jawab pada sang pencipta.

Filsafat merupakan ilmu tersusun dalam suatu tatanan struktur hierarki yang meletakkan metafisika sebagai dasar yang memunculkan beragam akar cabang. Akar cabang filsafat sebagai dasar pijakan munculnya beragam teori yang lazimnya dikenal dengan ilmu, dari filsafat inilah segala bangunan IPTEK terwujud dan tumbuh serta berkembang di semua sistem budaya dan peradaban manusia di dunia. Penyebabnya karena filsafat secara hakikat bagian dari suatu rumpun keilmuan yang khusus dan berdiri sendiri secara teoritis dan praktis, yang berkembang dalam bidangnya masing-masing guna menuntun manusia untuk mengembangkan budaya dan peradabannya.

Awal mula perkembangan filsafat ditandai dengan rencana umat manusia guna menjawab problematik seputar alam, manusia dan Tuhan. Dari situlah penyebab filsafat mampu melahirkan sainssains besar seperti fisika, biologi, kimia, etika, matematika dan metafisika yang menjadi pondasi pembentuk peradaban manusia (Latif, 2014). Maka, nyatalah bagi kita bahwa filsafat memang benar memegang peranan besar melalui penerapannya di semua bidang kehidupan manusia. Tidak satu pun bidang kehidupan manusia di dunia ini yang lolos dari jangkauan filsafat.

Menurut peneliti relevansinya hubungan filsafat dan ilmu pengetahuan di era Revolusi Industri 4.0 dan Society 5.0 saat ini atau dikenal dengan era disrupsi masyarakat harus tetap waspada terhadap perkembangan zaman, karena akan banyak permasalahan yang muncul dimasyarakat pascamodern oleh masifnya perkembangan ilmu pengetahuan dan teknologi itu sendiri. Ilmu 
pengetahuan baik eksakta maupun sosial telah mengalami transformasi dan perkembangan sangat pesat akibat adanya kritikkritik terhadap ilmu tersebut. Ditinjau dari sisi lain masyarakat saat ini telah dihadapkan oleh zaman canggih di mana teknologi berekspansi ke semua lini kehidupan manusia.

Counter discourse terhadap perkembangan IPTEK tidak dapat dilakukan, melainkan untuk dapat mengurangi dampak negatif dari adanya teknologi. Hal tersebut bisa masih dapat dilakukan oleh masyarakat dengan syarat mampu menganalisis kebutuhan mereka terhadap teknologi. Masyarakat saat ini harus kritis sebab kunci untuk menciptakannya masyarakat yang harmonis dan sejahtera di tengah perbedaan kebutuhan antar individu. Bila dikembalikan ke awal tujuannya dengan terciptanya masyarakat yang kritis dapat mengatasi terhadap segala hal menyangkut kehidupan, guna untuk menjalankan perubahan roda kehidupan yang bergulir dan terlaksana dengan cepat.

Konsep filsafat bisa dijadikan metode berpikir kritis dan mandiri. Hal ini sesuai dengan tantangan dan perubahan zaman saat ini yang hanya dapat dihadapi dengan kreatif oleh pribadi mandiri, kritis dan terbuka untuk peluang-peluang baru. Konsep filsafat ini akan dapat memberikan kontribusi yang sangat berarti bagi kehidupan. Sejalan dengan pemikiran Jurgen Habermas bahwa antara ilmu dan kepentingan manusia secara technical (teknik), pratical (praktis) dan emancipatory (emansipatoris) memiliki keterkaitan yang sangat erat untuk mengubah tatanan masyarakat yang lebih baik dan maju (Tasnur \& Sudrajat, 2020). Jika diterapkan dalam kehidupan masyarakat industri maka tujuan humanisasi dan emansipatoris akan dapat terwujud (Semiawan, 2006). Tetapi, perlu dipahami bahwa menciptakan masyarakat kritis terhadap situasi kekinian perlu pendalaman konsep filsafat untuk mewujudkan perubahan pola kehidupan masyarakat yang lebih maju.

Filsafat sendiri dijadikan renungan oleh manusia mengenai tentang kebenaran yang dapat membentuk karakter manusia menjadi harmonis. Tentu hal ini, sangat relevan sekali bila diterapkan di era Society 4.0 menuju Society 5.0 yang penuh 
keharmonisan. Era Revolusi Industri ini 4.0, ciri-ciri perilaku kehidupan masyarakat ditandai dengan berkembangnya dunia teknologi seperti internet, teknologi baru dalam ilmu data, teknologi nano, dan kecerdasan buatan, manusia dalam masyarakat harus memulai dengan santun penuh keseimbangan, agar senantiasa manusia berubah, berkembang menyesuaikan diri terhadap perubahan zaman yang ada.

Apalagi sekarang ini banyak dari sebagian masyarakat berbicara semena-mena dengan adanya perkembangan teknologi, sehingga mudah menyebar, dan bisa saja mudah memicu gejolak ketegangan. Maka, sudah seharusnya etika kebaikan dihidupkan kembali, ditanamkan sejak usia dini, tujuannya agar karakter masyarakat mampu mengendalikan keseimbangan diri, yang nantinya keharmonisan kehidupan masyarakat terbangun dari keluarga, kelompok, mengimbas terhadap masyarakat bangsa mencapai dunia, yang telah terangkai dengan jaringan komunikasi digital.

Sejalan dengan pendapat Rudy Harjanto \& Lasiyo (2018) kita harus belajar dari falsafah kehidupan dalam perspektif Tao Te Ching Lao Tsu atau jalan kebajikan. Falsafah Tao mengajarkan pada kita dalam kehidupan harus memiliki tiga warisan utama. Pertama, tentang cinta, dengan cinta membuat manusia menjadi berani. Kedua, tentang kesederhanaan, dengan kesederhanaan memungkinkan manusia dapat menjangkau berkelimpahan. Ketiga, kerendahan hati, dengan rendah hati memungkinkan manusia dapat mengisi posisi tertinggi. Berdasarkan falsafah Tao ketiga falsafah ini harus dijalankan dengan bersamaan, sebab dalam kehidupan tidak ada titik yang tetap; satu-satunya yang konstan dalam kehidupan adalah perubahan itu sendiri. Cara terbaik untuk menyikapi perubahan dalam menjalani kehidupan adalah menjadi seperti air, karena dapat memberikan manfaat, menunjang kehidupan semua dan melakukannya dengan kelembutan tanpa pertentangan.

Menurut peneliti falsafah tersebut memang sangat relevan sekali untuk menghadapi derasnya arus globalisasi di era digital ini 
dengan falsafah Tao Te Ching, karena kita benar-benar belajar arti roda kehidupan. Dalam menjalani roda kehidupan itu sendiri pastinya tidak akan terlepas dari arti perubahan. Maka, sikapi perubahan tersebut dengan arif dan bijak agar kita selalu diberikan kerendahan hati untuk selalu belajar, supaya dapat menyesuaikan diri terhadap perubahan zaman.

\section{KESIMPULAN}

Filsafat telah menjembatani lahirnya pendekatan multidisipliner yang sangat diperlukan, karena terbatas dan sempitnya kajian keilmuan terhadap realitas fisik yang sesungguhnya bersifat multidimensional. Ilmu pengetahuan adalah rangkaian aktivitas manusia yang rasional dan kognitif yang terdiri dari berbagai metode berupa aneka prosedur dan tata langkah sehingga menghasilkan kumpulan pengetahuan yang sistematis mengenai gejala-gejala kealaman, kemasyarakatan atau perorangan untuk tujuan mencapai kebenaran, memperoleh pemahaman, memberikan penjelasan, ataupun melakukan penerapan. Realitas hubungan filsafat dan ilmu pengetahuan adalah sama-sama hasil dari kegiatan berpikir manusia. Kegiatan manusia diartikan dalam sebuah prosesnya dan juga dalam hasilnya. Apabila dilihat dari hasilnya, ketiganya merupakan hasil daripada berpikir manusia secara sadar. Jika dilihat dari segi prosesnya, keduanya menunjukkan suatu kegiatan yang berusaha untuk memecahkan masalah-masalah dalam kehidupan manusia (untuk memperoleh kebenaran dan pengetahuan), dengan menggunakan metodemetode atau prosedur-prosedur tertentu secara sistematis dan kritis.

Filsafat dan ilmu pengetahuan merupakan jembatan atas perubahan dan perkembangan di dunia IPTEK. Berkembangnya teknologi saat ini dikenal dengan istilah Revolusi Industri 4.0 dan Society 5.0 di mana pola kehidupan manusia telah beralih dari tenaga manusia ke tenaga teknologi canggih seperti internet, robot, kecerdasan buatan dan komputer. Hal ini biasa dikenal dengan era disrupsi sebab akan muncul banyaknya permasalahan- 
permasalahan masyarakat yang dihadapi atas masifnya perkembangan IPTEK. Meskipun hal tersebut diawali oleh manusia dalam masyarakat yang santun penuh keseimbangan, manusia senantiasa terus berubah, berkembang menyesuaikan diri terhadap perubahan yang ada sesuai dengan zaman. Counter discourse terhadap perkembangan IPTEK tidak dapat dilakukan, melainkan untuk dapat mengurangi dampak negatif dari adanya teknologi tersebut. Masyarakat saat ini harus kritis sebagai kunci dalam menghadapi tantangan zaman serta mampu menganalisis kebutuhan mereka terhadap teknologi.

\section{DAFTAR PUSTAKA}

Agriyanto, R., \& Rohman, A. (2015). Rekonstruksi Filsafat Ilmu dalam Perspektif Perekonomian yang Berkeadilan. Jurnal AtTaqaddum, 7(1), 22-39. https://doi.org/10.21580/at.v7i1.1530

Bakhtiar, A. (2012). Filsafat Ilmu. Jakarta: PT Raja Grafindo Persada.

Carnap, R. (2012). An Introduction to the Philosophy of Science. New York: Dover Publication, Inc.

French, S., \& McKenzie, K. (2016). Rethinking outside the toolbox: Reflecting again on the relationship between philosophy of science and metaphysics. Poznan Studies in the Philosophy of the Sciences and the Humanities, 104(3), 25-54. https://doi.org/10.1163/9789004310827_003

Fukuda, K. (2020). Science, technology and innovation ecosystem transformation toward society 5.0. International Journal of Production Economics, 220(2), 107-129. https://doi.org/10.1016/j.ijpe.2019.07.033

Habibah, S. (2017). Implikasi Filsafat Ilmu terhadap Perkembangan Ilmu Pengetahuan dan Teknologi. DAR EL-ILMI : Jurnal Studi Keagamaan, Pendidikan Dan Humaniora, 4(1), 166-180. http://ejurnal.unisda.ac.id/index.php/dar/article/view/693 
Harjanto, R., \& Lasiyo. (2018). Filsafat Kehidupan dalam Perspektif Tao Te Ching Lao Tsu. Jakarta: Obor.

Hidayatullah, S. (2006). Relasi Filsafat dan Agama (Perspektif Islam). Jurnal Filsafat, 40(2), 128-148. https://doi.org/10.22146/jf.31271

Ibda, H. (2019). Filsafat Umum Zaman Now. Pati: CV. Kataba Group. Jalaludin. (2013). Filsafat Ilmu Pengetahuan. Jakarta: PT. Rajagrafindo Persada.

Juhaya. (2003). Aliran-Aliran Filsafat Dan Etika. Jakarta: Prenada Media Group.

Kirom, S. (2011). Filsafat Ilmu dan Arah Pengembangan Pancasila: Relevansinya Dalam Mengatasi Persoalan Kebangsaan. Jurnal Filsafat, 21(2), 99-118. https://doi.org/10.22146/jf.3111

Komara, E. (2012). Filsafat Ilmu dan Metodologi Penelitian. Bandung: PT Refika Aditama.

Ladyman, J. (2012). Understanding philosophy of science (Routledge (ed.)). https://doi.org/10.4324/9780203463680

Latif, M. (2014). Orientasi Ke Arah Pemahaman Filsafat Ilmu. Jakarta: Prenadamedia Group.

Levine, D. (2018). Auguste Comte and Positivism: The Essential Writings. Contemporary Sociology: A Journal of Reviews, 47(6), 677-688. https://doi.org/10.1177/0094306118805421c

Machamer, P. (2008). A Brief Historical Introduction to the Philosophy of Science. Cambridge: Cambridge University Press. https://doi.org/10.1002/9780470756614.ch1

Makhmudah, S. (2018). Hakikat Ilmu Pengetahuan dalam Perspektif 
Modern dan Islam. Jurnal Al-Murabbi, 4(2), 202-217. http://ejournal.kopertais4.or.id/mataraman/index.php/murabb i/article/view/3173

Maksum, A. (2015). Pengantar Filsafat Dari Masa Klasik Hingga Postmodernisme. Yogyakarta: Ar-Ruzz Media.

Mufid, F. (2013). Perkembangan Paradigma Epistemologi Dalam Filsafat Islam. Ulumuna Jurnal Studi Keislaman, 17(1), 19-40. https://doi.org/10.20414/ujis.v17i1.172

Nasution, T. A. (2016). Filsafat ilmu: Hakikat mencari pengetahuan. Yogyakarta: Deepublish.

Okasha, S. (2016). Philosophy of Science: Very Short Introduction. United Kindom: Oxford University Press.

Poespowardojo, T. . S., \& Seran, A. (2015). Filsafat Ilmu Pengetahuan. Jakarta: Kompas.

Prasetyo, B., \& Trisyanti, U. (2018). Revolusi Industri 4.0 dan Tantangan Perubahan Sosial. IPTEK: Journal of Proceedings Series, 5, 22-28. https://doi.org/10.12962/j23546026.y2018i5.4417

Rapar, J. H. (2001). Pengantar Filsafat. Yogyakarta: Kanisius.

Rofiq, M. N. (2018). Peranan Filsafat Ilmu Bagi Perkembangan Ilmu Pengetahuan. Falasifa, 9(1), 161-175. https://doi.org/10.36835/falasifa.v9i1.112

Rohida, L. (2018). Pengaruh Era Revolusi Industri 4.0 terhadap Kompetensi Sumber Daya Manusia. Jurnal Manajemen Dan Bisnis Indonesia, 6(1), 187-198. https://doi.org/10.31843/jmbi.v6i1.187

Salam, B. (2012). Pengantar Filsafat. Jakarta: PT. Bumi Aksara. 
Savitri, A. (2019). Revolusi Industri 4.0: Mengubah Tantangan Menjadi Peluang di Era Disrupsi 4.0. Yogyakarta: Penerbit Genesis.

Schrijvers, J. (2018). Contemporary philosophy of religion: An introduction. In Tydskrif vir Geesteswetenskappe. Cambridge: Cambridge University Press. https://doi.org/10.17159/22247912/2018/v58n3a1

Schwab, K. (2019). Revolusi Industri Keempat. In The Fourth Industrial Revolution. Jakarta: PT. Gramedia Pustaka Utama.

Semiawan, S. Y. (2006). Panorama Filsafat Ilmu Landasan Perkembangan Ilmu Sepanjang Zaman. Jakarta: Teraju.

Setiawan, J., \& Sudrajat, A. (2018). Pemikiran Postmodernisme dan Pandangannya Terhadap Ilmu Pengetahuan. Jurnal Filsafat, 28(1), 26-46. https://doi.org/10.22146/jf.33296

Soyomukti, N. (2011). Pengantar Filsafat Umum. Yogyakarta: ArRuzz Media.

Suaedi. (2016). Pengantar Filsafat Ilmu. Bandung: Alfabeta.

Surojiyo. (2008). Ilmu Filsafat Suatu Pengantar. Jakarta: PT. Bumi Aksara.

Tafsir, A. (2005). Filsafat Ilmu Mengurai Ontologi, Epistemologi, dan Aksiologi Pengetahuan. Jakarta: PT Remaja Rosdakarya.

Tasnur, I., \& Sudrajat, A. (2020). Teori Kritis: Perkembangan dan Relevansinya Terhadap Problematika di Era Disrupsi. Jurnal Yaqzhan, 6(1), 32-51. https://doi.org/10.24235/jy.v6i1.5894

Varpio, L., \& Macleod, A. (2020). Philosophy of Science Series: Harnessing the Multidisciplinary Edge Effect by Exploring Paradigms, Ontologies, Epistemologies, Axiologies, and Methodologies. Academic Medicine, 955(5), 686-689. 
https://doi.org/10.1097/ACM.0000000000003142

Wahana, P. (2016). Filsafat Ilmu Pengetahunaan. Yogyakarta: Pustaka Diamond.

Waston. (2019). Strategi Menang Dalam Revolusi Industri 4.0 (Perspektif Filsafat Thomas Kuhn). URECOL: Proceeding of The 10th University Research Colloquium 2019: Bidang Pendidikan, Humaniora Dan Agama, 343-354.

Wilujeng, S. W. (2014). Ilmu dalam Perspektid Filsafat (Suatu Upaya Mengembalikan Ilmu pada Hakikatnya). Jurnal Humanika, 2(2), 93-102. https://doi.org/10.14710/humanika.20.2.93-102

Zaprulkhan. (2016). Filsafat Umum Sebuah Pendekatan Tematik. Jakarta: PT. Raja Grafindo Persada. 